\title{
MELURUSKAN BEBERAPA PERSEPSI TENTANG POLIGAMI (TAFSIR SURAT AL-NISĀ' AYAT 3 DAN 129)
}

\section{Muhammad Kasim Saguni}

Sekolah Tinggi Ilmu Islam dan Bahasa Arab (STIBA) Makassar,

Jl. Inspeksi PAM Manggala-Antang Makassar

Email : qasimsaguni@gmail.com

\section{Syandri}

Sekolah Tinggi Ilmu Islam dan Bahasa Arab (STIBA) Makassar, Jl. Inspeksi PAM Manggala-Antang Makassar Email : qasimsaguni@gmail.com

\begin{tabular}{ll}
\hline Keywords : & ABSTRACT \\
\cline { 2 - 3 } Perception, polygamy & This study describes some false perceptions of polygamy based on the \\
Qur'an Chapter An-Nisä' verse no. 3 and 129. The method used \\
in this study is library research. Various sources were collected to \\
obtain data and facts. These data were collected sorted and selected \\
and then analyzed to answer the first two main subjects: \\
understanding and history of polygamy, second: correcting some of the \\
wrong perceptions about polygamy. The results of this study indicate \\
that polygamy is the marriage of a man with more than one woman, \\
which has been widely known and practiced by the Muslim in \\
various parts of the world. As for the false perception, the false \\
perceptions are caused by lack of proper understanding about pure \\
religious teachings according to the Qur'an, the Sunnah of the \\
Prophet and the understanding of zealous and pious Islamic scholars. \\
Another cause is due to the a priori behavior and lust. Moreover, the \\
Muslim haters take advantage over the issue of polygamy to insult \\
Islam with various heinous accusations where these insults coming \\
from hate speech and dishonesty in judging this issue.
\end{tabular}




\section{PENDAHULUAN}

Poligami merupakan isu klasik yang selalu menarik perhatian untuk diperbincangkan dan didiskusikan oleh kaum Adam apalagi kaum Hawa. Menarik bagi kaum Hawa, sebab jika poligami diperbolehkan itu berarti kaum Adam mendapatkan legitimasi syari'ah (baca: agama) untuk menikah lebih dari seorang istri. Sedangkan bagi sebagian besar kaum Hawa merupakan momok bahkan perkara yang paling pantang bagi mereka. Hal itu disebabkan karena umumnya karakteristik kaum Hawa tidak ingin diduakan dalam hidupnya. Kalimat yang sering kita dengarkan dari mereka adalah: "Siapa perempuan yang mau dimadu?".

Sebenarnya, poligami sudah dikenal dan dipraktekkan oleh bangsabangsa kuno, seperti Athena, Cina, India, Babilonia, Asyiria dan Mesir Kuno. Pada bangsa-bangsa ini tidak ditemukan batasan maksimal dalam poligami. Contohnya, undang-undang Cina kuno mengizinkan laki-laki untuk mempunyai sampai 130 istri. Bahkan, seorang bangsawan Cina mempunyai 30.000 istri. $^{1}$

Dr. Mustafa Al-Siba'i selanjutnya mengatakan:

Agama Yabudi mengizinkan poligami dengan tanpa memberikan batasan maksimal. Semua nabi-nabi bangsa Yabudi babkan mempunyai banyak istri. Disebutkan di dalam kitab Taurat babwa Nabi Sulaiman

${ }^{1}$ Mustafa Al-Siba'i, Al-Mar'ah bain al-Figh wa Al-Qanun diterjemahkan oleh Muhammad Muchson Anasy, Mengapa Poligami (Cet.l; AzanYayasan Adjeng Suharno, 1423H/Oktober 2002 M), h.2 mempunyai 700 istri yang merdeka dan 300 budak perempuan. ${ }^{2}$

Kelompok anti Islam, menjadikan isu poligami sebagai salah satu argumen untuk menuduh Islam sebagai agama yang mendiskriminasi kaum perempuan. Bahkan dalam satu situs JIL (Jaringan Islam Liberal) ditemukan sebuah artikel yang diberi judul: "Poligami sebagai Bentuk Kekerasan yang Paling Nyata atas Harkat dan Martabat Perempuan sebagai Manusia di dalam Hukum, Sosial Budaya dan Agama". ${ }^{3}$

Sementara itu kalangan awam dari ummat Islam, sering membenturkan makna dua ayat yang dijadikan fokus pembahasan dalam pembahasan ini yaitu surat al-Nisā' $/ 4$ : 3 dan al-Nisāa $/ 4: 129$. Ayat 3 dari surat al-Nisā' membolehkan poligami sampai empat tapi dengan syarat mampu berbuat adil, namun upaya berbuat adil itu tidaklah mungkin terwujud karena pada ayat 129 Allah SWT telah menafikannya dengan firmanNya:

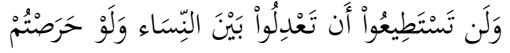

Terjemahnya:

"Dan kamu sekali-kali tidak akan dapat berlaku adil di antara istri- istri (mu), walaupun kamu sangat ingin berbuat demikian...."4

Pemahaman seperti ini tidak saja dianut oleh sebagian besar kaum awam dalam Islam, tetapi juga tidak sedikit jumlahnya dari kalangan Da'i dan Muballigh yang berpemahaman seperti itu.

\footnotetext{
${ }^{2}$ Mustafa Al-Siba'i, Al-Mar'ah bain al-Fiqh wa Al-Qanun diterjemahkan oleh Muhammad Muchson Anasy, Mengapa Poligami, h.2. ${ }^{3}$ www.lbh-apik.or.id/sm-perspoligami.htm

${ }^{4} K e m e n t r i a n$ Agama, Al-Qur'an dan Terjemahannya (Depok, Sabiq, 2012), h. 99.
} 
Berdasarkan latar belakang yang telah diuraikan di atas, maka terdapat beberapa masalah yang perlu dibahas dalam tulisan ini, yaitu:

1. Bagaimana Pengertian dan Sejarah Poligami?

1. Bagaimana Meluruskan beberapa persepsi yang keliru tentang poligami?

\section{PEMBAHASAN}

\section{A. Sejarah Poligami}

Osman Raliby dalam Kamus Internasional sebagaimana dikutip oleh Sufyan Raji Abdullah, menjelaskan bahwa kata poligami berasal dari bahasa Yunani "polygamie", poly berarti banyak dan gamie berarti laki-laki. Jadi poligami berarti laki-laki yang beristri lebih dari satu orang wanita dalam satu ikatan perkawinan. ${ }^{5}$

Drs.Sidi Ghazalba mengatakan bahwa:

"Poligami adalah perkawinan antara seorang laki-laki dengan lebih dari satu orang perempuan. Lawannya adalah poliandri, yaitu perkawinan antara seorang perempuan dengan beberapa orang laki-laki. Sebenarnya istilah poligami itu mengandung pengertian poligini dan poliandri. Tetapi karena poligami lebih banyak dikenal terutama di Indonesia dan negara-negara yang memakai hukum Islam, maka tanggapan tentang poligini ialah poligami."6 Dalam bahasa Arab, poligami diistilahkan dengan al-Ta'addud.

${ }^{5}$ Sufyan Raji Abdullah, Poligami dan Eksistensinya, (Cet.l; Pustaka Al-Riyadl, 2004), h. 49.

${ }^{6}$ Sidi Ghazalba, Menghadapi Soal-soal Perkawinan, (Cet.l; Pustaka Antara, Jakarta, 1975), h. 25
Sebelum datangnya Islam yang dibawa oleh Nabi Muhammad saw, praktek poligami sudah dikenal luas dan tidak terbatas pada beberapa orang istri saja. Para raja serta para kaisar dikalangan bangsa Romawi melakukan praktek poligami, seperti kaisar Sila mempunyai 5 orang istri (permaisuri) dan kaisar Bombay memiliki 4 orang istri. Sementara seorang bangsawan Cina kuno mempunyai istri sekitar 30.000 orang, padahal undang-undang Cina kuno hanya mengizinkan laki-laki untuk mempunyai istri sampai 130 orang. ${ }^{7}$

Para Nabi kaum Bani Isra'il selain Nabi Isa As juga berpoligami. Nabi Dawud As beristri lebih dari dua orang. Nabi Ibrahim As beristri 2 orang wanita. Nabi Ya'kub As mempunyai istri 4 orang dan Nabi Sulaiman As mempunyai 100 istri. $^{8}$

Di kalangan bangsa Arab Jahiliyah, poligami sangat membudaya, baik di kalangan bangsawan maupun rakyat jelata. Poligami yang mereka praktekkan juga tidak ada batasannya. Sebagai bukti, adalah Qais bin Harits mempunyai 8 orang istri, Ghailan bin Umaiyyah mempunyai 15 orang istri, Naufal bin Mu'awiyah mempunyai 5 orang istri. Abdul Muthalib bin Hasyim mempunyai 6 orang istri, Abu Sufyan mempunyai 6 orang istri. Shafwan bin Umaiyyah mempunyai 6 orang istri.'

Setelah Rasulullah saw diutus, maka praktek poligami diatur sedemikian rupa dan dibatasi sampai empat orang istri saja. Hal ini diatur dalam surat An-Nisaa ayat 3 dan

\footnotetext{
${ }^{7}$ Sufyan Raji Abdullah, Poligami dan Eksistensinya, h. 49.

8Sidi Ghazalba, Menghadapi Soal-soal Perkawinan, h. 53.

${ }^{9}$ Sufyan Raji Abdullah, Poligami dan Eksistensinya, h. 57.
} 
Sabda Nabi saw, dari Harits bin Qais $\mathrm{R} a$, berkata Musaddad ibn Umairah dan berkata Wahab al-Asady, ia berkata:

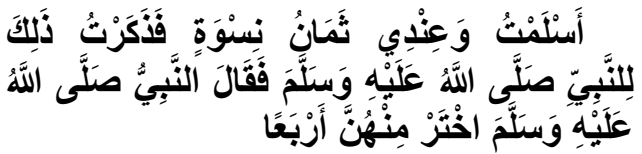

Artinya:

Saya masuk Islam pada saat itu saya mempunyai 8 orang istri, maka hal itu saya beritakan kepada Rasulullah saw, maka beliau bersabda: "Pilihlah 4 orang istri saja diantara mereka. $^{10}$

Pada saat itu mereka yang masuk Islam dan mempraktekkan poligami lebih dari 4 orang istri, harus meninggalkan yang lainnya (talaq) dan dibolehkan untuk menyisakan 4 orang saja.

\section{B. Ayat-ayat Poligami dan Tafsirnya}

Ada dua ayat dalam al-Qur'an yang secara khusus mengatur poligami, kedua ayat itu adalah: Surat alNisā'/4: 3 dan 129.

1. Surat al-Nisā'/4:3.

Allah Subhanahu Wata'ala berfirman:

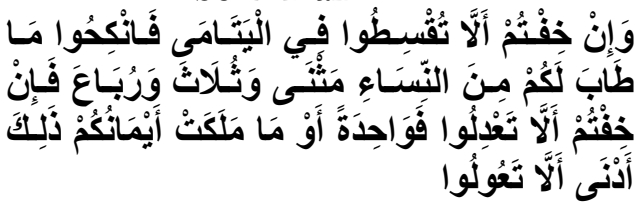

Terjemahnya:

Dan jika kamu takut tidak akan

dapat berlaku adil terhadap

(hak-hak) perempuan yatim

(bilamana kamu

mengawininya), maka

kawinilah wanita-wanita (lain)

${ }^{10} A b u ̄$ Dāud Sulaimān Ibn Al-Asy'aś alSijistanī, Sunan Abī Dāud, Jilid II, (Bairūt, Dār alKitāb al-Arabī, 1346 H), h. 239. yang kamu senangi: dua, tiga

atau empat. Kemudian jika

kamu takut tidak akan dapat

berlaku adil, maka (kawinilah)

seorang saja, atau budak-budak

yang kamu miliki. Yang

demikian itu adalah lebih dekat

kepada tidak berbuat aniaya. ${ }^{11}$

\section{Tafsinny:}

Imam al-Bukhari

meriwayatkan: "Telah menceritakan kepada kami 'Abdul 'Azīz bin 'Abdullāh, telah menceritakan kepada kami dari Ibrāhīm bin Sa'ad dari Șalih bin Kaisān dari Ibnu Syihāb, ia berkata: 'Urwah bin al-Zubair mengabarkan kepadaku bahwa ia bertanya kepada 'Aisyah tentang firman Allah :

Terjemahnya:

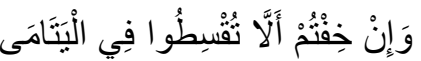

"Dan jika kamu takut tidak akan dapat berlaku adil terbadap perempuan yatim bilamana kamu mengawini"

Beliau menjawab: "Wahai anak saudariku, anak yatim perempuan yang dimaksud adalah wanita yatim yang berada pada pemeliharaan walinya yang bergabung dalam hartanya. "Sedangkan ia menyukai harta dan kecantikannya. Lalu, walinya ingin mengawininya tanpa berbuat adil dalam maharnya, hingga memberikan mahar yang sama dengan mahar yang diberikan orang lain. Maka, mereka dilarang untuk menikahinya kecuali mereka dapat berbuat adil kepada wanita-wanita tersebut dan memberikan mahar yang terbaik untuk mereka. Dan mereka diperintahkan untuk menikahi wanita-wanita yang

${ }^{11}$ Kementrian Agama, Al-Qur'an dan Terjemahannya, h. 77. 
Website: https://journal.stiba.ac.id

ISSN : 2685-7537 (online) 2338-5251 (Printed)

mereka sukai selain mereka selain mereka. ${ }^{12}$

Syaikh Imad Zaki Al-Barudi dalam Tafsir Al-Qur'an Al-'Adrim Li An-Nisa', berpendapat bahwa yang dimaksud "takut" dalam ayat tersebut adalah sangkaan kuat dan bukan sesuatu yang yakin dan pasti. Dimana dalam perkiraan kuatnya dia tidak akan mampu berlaku adil terhadap anak perempuan yatim itu. ${ }^{13}$

Sedangkan makna "perempuan yatim" terjadi perbedaan pendapat dari Ulama, ada yang mengatakan perempuan yatim yang belum baligh, seperti pendapat Abu Hanifah, sedangkan Imam Malik dam Imam Syafi'i berpendapat sebaliknya, mereka berdua mengatakan:

"Tidak boleh nikah dengan perempuan yatim yang belum baligh hingga dia baligh, dan memungkinkan untuk diminta pendapatnya, serta ada izin darinya."

Nampaknya pendapat Imam Malik dan Imam Syafi'i inilah yang lebih kuat (Wallahu Ta'ala 'Alam) sebab dalam ayat 127 dari surat AlNisā' disebutkan وَيَنَتَنْتُونَكَ فِن النِّسَاءٍ (Dan mereka meminta fatwa kepadamu tentang para wanita) kata Al-Nisä, disini berlaku untuk wanita-wanita yang telah dewasa, demikian pula dengan firmanNya:

${ }^{12}$ Imāduddīn Abul Fidā' Ismā’̄̄l Ibn Kasiīr, Tafsīr Al-Qur'ān Al-'Ažìm, Jilid I, (t.c., Al Madīnah Al-Munawwarah: Maktabah Al-'Ulūm wa AlHikam, 1413 H -1993 M), h.426.

${ }^{13}$ Syaikh Imād Zaki Al-Barudi,, Tafsir AlQur'an Al-Adzhim li An-Nisa' diterjemahkan oleh Samson Rahman, Tafsir Wanita, (Cet.l; Jakarta Timur: Pustaka Al-Kautsar, 2004), h.275

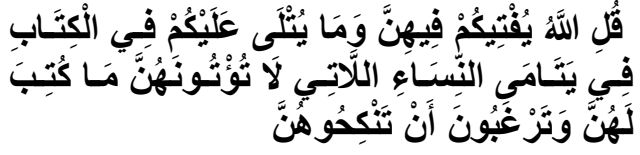

Terjemahnya:

Katakanlah: "Allah member fatwa kepadamu tentang mereka, dan apa yang dibacakan kepadamu dalam al-Quran (juga memfatwakan) tentang para wanita yatim yang kamu tidak memberikan kepada mereka apa yang ditetapkan untuk mereka, sedang kamu ingin mengawini mereka) disana sangat diperhatikan kata An-Nisaa (wanita dewasa) dan termasuk di dalamya adalah wanita yatim. ${ }^{14}$

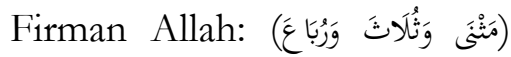
"dua, tiga atau empat" Maknanya: Nikahilah oleh kalian wanita-wanita yang kalian inginkan selain mereka. Jika kalian ingin silahkan dua, jika ingin silahkan tiga, dan jika ingin silahkan empat. Sebagaimana firman Allah SWT dalam QS Fātị/35: 1.

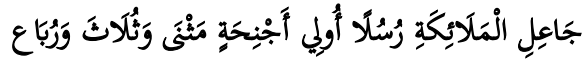

Terjemahanya:

Yang menjadikan malaikat sebagai utusan-utusan (untuk mengurus berbagai macam urusan) yang mempunyai sayap, masingmasing (ada yang) dua, tiga, dan empat.

Maknanya, diantara mereka ada yang memiliki dua sayap, ada yang tiga dan ada yang empat. Hal tersebut tidak berarti meniadakan adanya Malaikat yang (memiliki jumlah sayap) selain dari itu, karena terdapat dalil yang menunjukkannya. Berbeda dengan kasus pembatasan empat wanita bagi laki-laki dari ayat ini,

${ }^{14}$ Syaikh Imād Zaki Al-Barudi,, Tafsir AlQur'an Al-Adzhim li An-Nisa' diterjemahkan oleh Samson Rahman, Tafsir Wanita, h.276 
sebagaimana yang dikatakan oleh Ibnu 'Abbās dan Jumhur ulama, karena kedudukannya adalah posisi pemberian nikmat dan mubah. Seandainya dibolehkan menggabung lebih dari empat wanita, niscaya akan dijelaskan. ${ }^{15}$

Imam Al-Syāfi'̄i memberikan komentar tehadap ayat ini, bahwa:

Sunnah Rasulullah saw yang memberikan penjelasan dari Allah, menunjukkan bahwa tidak diperbolehkan bagi seseorang selain Rasulullah saw untuk menghimpun lebih dari empat wanita.

Hal ini didasarkan pada sabda Nabi saw tatkala Ghailan bin Salamah al-Śaqafì masuk Islam, saat itu ia memiliki 10 orang istri. Maka Nabi saw mengatakan: "Pilihlah 4 orang diantara mereka. Begitupula yang diriwayatkan oleh al-Syāfi'î, al-Tirmiżī, Ibnu Mājah, Daraquțnī, al-Baihaqi dan yang lainnya. Dan itu pula yang diriwayatkan oleh Malik dar Az zuhri secara mursal. Abu zur'ah berkata; "Inilah yang lebih shabih."16

Firman-Nya QS. Al-Nisā'/4: 3.

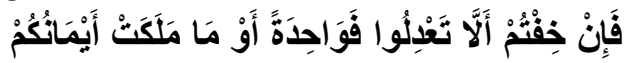

Terjemahnya:

Dan jika kamu takut tidak akan dapat berlaku adil, maka kawinilah seorang saja atau budak-budak yang kamu miliki." ${ }^{17}$

Abdurrahmān Al-Sa'dī dalam tafsirnya Taisir al-Karim al-Rahmān fi Tafsir Kaläm al-Mannān memberikan komentar terhadap potongan ayat

\footnotetext{
${ }^{15}$ Imāduddīn Abul Fidā' Ismā'îl Ibn Kasiīr, Tafsìr Al-Qur'ān Al-'Ažìm, Jilid I, h. 426. ${ }^{16}$ Imāduddīn Abul Fidā' Ismā'îl Ibn Kaṡīr, Tafsìr Al-Qur'ān Al-'Ażīm, Jilid I, h. 426.

${ }^{17}$ Kementrian Agama, Al-Qur'an dan Terjemahannya, h. 77.
}

tersebut di atas: "...dan jika kamu takut dari sesuatu dari hal ini (berlaku aniaya dan zalim serta tidak dapat menunaikan hak-haknya), maka kurangilah menjadi satu saja atau (cukuplah) dengan budak-budak yang kamu miliki, karena hal itu tidak mewajibkan pembagian (giliran) pada budak-budak yang ia miliki." Selanjutnya beliau mengatakan dengan ayat berikutnya ذَلِكَ (Yang demikian itu) yakni memilih satu saja atau apa yang kamu miliki berupa budakbudak. أَدْنَ أَلَّالَتُعُؤُوا yakni, lebih dekat supaya kamu tidak berbuat dzalim (aniaya)." ${ }^{\prime 18}$

\section{Surat Al-Nisā/4:129.}

Allah SWT berfirman:

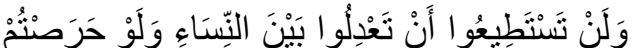

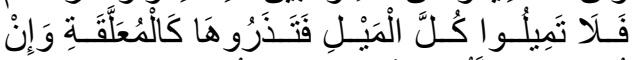

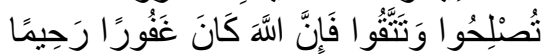

Terjemahnya:

Dan kamu sekali-kali tidak

akan dapat berlaku adil di

antara isteri- isteri $(\mathrm{mu})$,

walaupun kamu sangat ingin

berbuat demikian, karena itu

janganlah kamu terlalu

cenderung (kepada yang

kamu cintai), sehingga kamu

biarkan yang lain terkatung-

katung. Dan jika kamu

mengadakan perbaikan dan

memelihara diri (dari

kecurangan), maka

sesungguhnya Allah Maha

\footnotetext{
${ }^{18}$ Abdurrahmān Ibn Nāșir Al-Sa'dī, Taisīr al-Karīm al-Rahmān Fi Tafsìr Kalām al-Mannān ,Jilid I, (t.c., Dammām: Dār al-Dakhair, 1414H1994M), h.131.
} 
Pengampun lagi Maha

Penyayang. ${ }^{19}$

\section{Tafsimya:}

Imām Al-Ṭabarī memberikan penjelasan tentang ayat ini:

Yakni Kalian tidak mampu berbuat adil wahai laki-laki, yaitu kalian menyamakan diantara istri-istri kamu dalam mencintai mereka dengan hati hingga kalian dianggap berlaku adil diantara mereka dalam perkara itu, maka tidak mungkin di hati kalian ada sifat cinta kepada sebagian mereka yang sama dengan kepada yang lain, karena yang demikian itu bukanlah milik kalian dan bukan hak kalian.

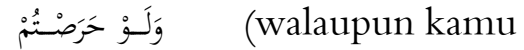

sangat ingin berbuat demikian), yaitu dalam hal mempersamakan mereka dalam hal kecintaan.

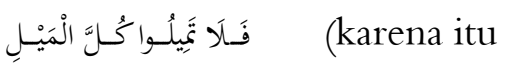

janganlah kamu terlalu cenderung

(kepada yang kamu cintai),yakni

janganlah kalian berpaling sepenuhnya dari yang kalian tidak cintai hingga membiarkan kalian berbuat zalim/aniaya terhadapnya dalam perkara yang wajib untuk mereka, yaitu pembagian malam, pemberian nafkah dan pergaulan yang baik.

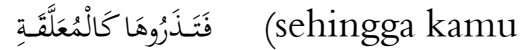

biarkan yang lain terkatung-katung),

yakni kalian meninggalkannya ibarat perempuan yang tak bersuami atau ibarat janda." ${ }^{20}$

Sedangkan al-Qurțubī dalam tafsirnya al-Jāmi' li-Abkeàm al-Qur'àn, mengatakan: "tidak ibarat wanita yang

\footnotetext{
${ }^{19}$ Kementrian Agama, Al-Qur'an dan Terjemahannya, h. 99.

${ }^{20} \mathrm{Abī} \mathrm{Ja'far} \mathrm{bin} \mathrm{Jarīr} \mathrm{Al-Ṭabarī,} \mathrm{Jāmi'} \mathrm{Al-}$ Bayān Fi Ta'wīl Al-Qur'an, Jilid IV, (Cet.III, Dammām, Dār al-Kutub, 1420H-1994M), h.131.
}

ditalak dan tidak juga ibarat wanita yang bersuami. ${ }^{21}$

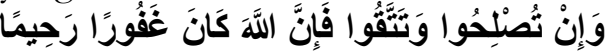

(Dan jika kamu mengadakan

perbaikan dan memelihara diri (dari

kecurangan), maka sesungguhnya

Allah Maha Pengampun lagi Maha

Penyayang). Yakni jika kalian

berdamai dalam perkara-perkara kalian dan kalian gilir dengan adil sesuai kemampuan kalian, serta kalian bertaqwa kepada Allah dalam semua kondisi, niscaya Allah akan mengampuni kalian terhadap kecenderungan kalian kepada sebagian istri-istri kalian. ${ }^{22}$

\section{Meluruskan Beberapa Persepsi Yang Keliru Tentang Poligami \\ Di tengah-tengah ummat} Islam, umumnya kaum wanita, menyebar beberapa persepsi yang keliru tentang poligami dalam Islam, diantaranya:

1. Poligami tidak mungkin diterapkan karena tidak mungkin berbuat adil.

Diantara dalil yang seringkali digunakan untuk menolak kebolehan pologami adalah QS. Al-Nisā'/4:129 seperti yang telah dipaparkan sebelumnya. Bahwa Allah SWT membolehkan laki-laki menikahi wanita sampai empat orang, dengan syarat ia dapat berbuat adil dengan semua istrinya. Tetapi hal itu tidaklah mungkin diwujudkan, sebab menurut mereka, dalam ayat ini Allah sudah menafikan hal tersebut di dalam QS. Al-Nisā'/4:129.

${ }^{21}$ Muḥammad bin Aḥmad Al-Qurțubī, AlJāmi' Li Ahkām Al-Qur'an, Jilid III, (t.c. Dammām, Dār Al-Hadīs, 1423H/2002 M). h.354.

${ }^{22}$ Imāduddīn Abul Fidā' Ismā’̄il Ibn Kasiīr, Tafsīr Al-Qur'ān Al-'Azīm, Jilid I, h.534 
Pemahaman seperti ini jelas merupakan kekeliruan yang besar, sebab (seperti yang telah dijelaskan dalam uraian tafsir di atas), bahwa makna keadilan yang dituntut bagi seorang laki-laki yang berpoligami adalah keadilan labiriyah, seperti pembagian malam, pemberian nafkah dan pergaulan yang baik. Dan semua hal ini adalah sesuatu yang mungkin dilakukan jika lelaki tersebut memiliki kemampuan lahiriyah dan kesadaran akan tanggungjawab berpoligamis sebagaimana yang telah dipraktekkan Rasulullah saw.

Adapun keadilan batiniyah (kecintaan hati), akan tetap sesuai firman Allah Walan Tastati' $\bar{u}$ (kalian pasti tidak mampu), karena itu bukanlah keadilan ini yang dituntut melainkan keadilan nafkah dan pergaulan yang baik.

\section{Dibolehkan berpoligami sampai 9 orang istri}

Ada juga dikalangan ummat Islam yang salah menerjemahkan makna dari QS. Al-Nisā'/4:3. Firman Allah SWT "maṢnā, waśuläśa wa rubä" diterjemahkan dalam bentuk penjumlahan yaitu $2+3+4$ menjadi 9. Selain itu mereka juga menunjuk praktek poligami Rasulullah Saw yang beristrikan 9 orang wanita.

Mengenai alasan penjumlahan tadi, Ibnul 'Arabā dalam Abkēm AlQur'än, mengatakan:

Ada kaum dari kalangan jubhal (orang-orang yang sangat bodoh) menyangka bahwa dibolehkan seorang laki-laki beristri 9 orang. Mereka tidak mengetahui bahwa perkataan másnà dalam bahasa Arab bermakna dua-dua (satu orang boleh dua), waśuläs bermakna tiga-tiga (satu orang boleh tiga) dan waruba' bermakna empat- empat (satu orang boleh empat).

Selanjutnya Ibnul 'Arabī mengatakan: Sekiranya Allah Ta'ala mengatakan

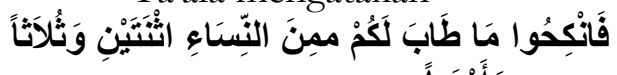

Terjemahnya:

$$
\text { وَأَزْبَعَاً }
$$

"Maka dengan yang demikian itu dibolehkan menikahi wanita sampai Sembilan orang." ${ }^{23}$

Sedangkan Rasulullah Saw menikah sampai Sembilan orang, adalah merupakan kekhususan bagi beliau. Seperti yang dikatakan oleh Ibnu Katsir:

"Hal ini menurut para Ulama termasuk kekhususan (min khashaishibi) bagi Nabi Shallallabu 'Alaibi Wasallam sendiri, bukan untuk ummatnya; karena adanya hadits-hadits yang menunjukkan kepada pengertian tersebut, yaitu membatasi istri hanya sampai empat orang. ${ }^{24}$

Selain adanya beberapa persepsi yang keliru tentang poligami, juga yang tak kalah pentingnya untuk dijawab, adalah tuduhan kelompok anti Islam terhadap kebolehan poligami. Diantaranya:

1. Penulis mengutipkan sebuah wawancara Dr.Mustafa Al-Siba'i dengan seorang baba yang juga ketua yayasan Baba Yosua (sebuah yayasan Yahudi) tatkala Mustafa Al-Siba'i berkunjung di Kota Dublin pada tahun $1956 .{ }^{25}$

\footnotetext{
${ }^{23} \mathrm{Abū}$ Bakr Muḥammad Ibn Abdillāh Ibnu Al-Arabī, Ahkām Al-Qur'ān, Jilid I, (t.c.Beirut, Dār Al-'Ilmiyah, 1417H/1996 M), h.408. ${ }^{24}$ Imāduddīn Abul Fidā' Ismā’īl Ibn Kaṡīr, Tafsìr Al-Qur'ān Al-'Ażīm, Jilid I, h.426.

${ }^{25}$ Mustafa Al-Siba'i, Al-Mar'ah bain alFiqh wa Al-Qanun diterjemahkan oleh
} 
Mustafa (M) berkata padanya, "Mengapa kalian menuduh Islam dan Nabinya, khususnya dalam buku-buku kurikulum, dengan tuduhan yang tidak pantas diucapkan pada masa di mana bangsa-bangsa telah saling mengenal dan berbagai budaya saling berinteraksi?

Baba (B): "Kami, bangsa Barat, tidak bisa menghormati seorang lakilaki yang menikah dengan sembilan wanita," jawabnya.

Saya (M) bertanya, "Apakah kalian menghormati Nabi Daud dan Sulaiman?"

(B): "Tentu. Bagi kami, mereka berdua adalah bagian dari nabi-nabi bangsa Israel."

Saya (M) menimpalinya, "Nabi Daud mempunyai Sembilanpuh Sembilan istri. Kemudian Daud menikah dengan isteri salah seorang panglimanya untuk melengkapi jumlah isterinya menjadi Seratus. Seperti yang diterangkan Taurat, Sulaiman mempunyai Tujuh Ratus istri dari wanita-wanita yang merdeka, dan Tiga Ratus istri dari budak-budak wanita. Mereka adalah wanita-wanita tercantik pada zamannya. Lalu, bagaimana kalian bisa menghormati seorang lakilaki yang menikah dengan Seribu wanita, sementera itu, kalian tidak bisa menghormati yang hanya menikah dengan sembilan wanita ? Mengapa kalian tidak bisa menghormati laki-laki menikah dengan sembilan wanita, delapan di antara mereka adalah janda, kaum ibu, yang sebagian di antaranya tua usianya, dan hanya seorang yang dinikahi dalam keadaan gadis?"

Sang Baba terdiam, lalu dia berkata, "Saya telah salah ucap. Maksud saya, kami, bangsa Barat, tidak bisa menikah lebih dari satu wanita.

Muhammad Muchson Anasy "Mengapa Poligami", h.54-56.
Bagi kami, seseorang yang menikah dengan beberapa wanita adalah aneh, atau hanya menuruti kehendak nafsu."

Saya berkata padanya, "Lantas, apa pendapat Anda tentang Daud dan Sulaiman dan nabi-nabi Israel yang lain, hingga Ada, yang mempraktekkan poligami?"

Dia (B) terdiam, tak mampu memberikan jawaban!

2. Poligami sebagai bentuk kekerasan yang paling nyata atas harkat dan martabat perempuan sebagai manusia di dalam hukum, sosial, budaya dan Agama. Pernyataan ini diungkapkan oleh di salah satu situs JIL ketika menanggapi secara sinis anugerah "Poligami Award" yang diprakarsai oleh Puspo Wardoyo.

Perlu diketahui bahwa praktek poligami tidak hanya dibolehkan/dipraktekkan di dalam Islam, tetapi sejak lama poligami ini sudah dikenal dan membudaya di berbagai belahan dunia. Poligami sudah dipraktekkan oleh bangsa Israil, bangsa Romawi dan Yunani bahkan ada yang tidak dinikahi secara resmi, di kalangan kaum Nasrani yang dipelopori oleh kaisar Konstantinopel dan putranya, kaisar Valavius Valentine malah menetapkan undangundang yang membolehkan poligami. Ajaran Zoroaster mengajarkan kepada pengikutnya orang-orang Persia supaya berpoligami dan memiliki wanita-wanita idaman lain (WIL) sebab menurutnya bangsa yang sedang berperang pasti sangat membutuhkan tenaga-tenaga muda. Budaya bangsa Mesir Kuno juga tidak melarang berpoligami, bangsa India dan bangsa Arab di zaman Jahiliyah. ${ }^{26}$

Sampai sekarang di Barat sangat membudaya praktek poligami, dengan

${ }^{26}$ Sufyan Raji Abdullah, Poligami dan Eksistensinya. h.53-57. 
gonti-ganti pasangan, karena itu pasangan wanita tidak disebut sebagai istri tetapi sebagai teman atau kasih. Sebenarnya poligami jenis ini lebih tepat disebut "perselingkuban". Hubungan ini adalah poligami yang mendewakan nafsu dan egoisme, yang tidak meniscayakan adanya orang yang harus bertanggungjawab. ${ }^{27}$

Pertanyaannya, yang mana sesungguhnya pelaku kekerasan yang paling nyata atas harkat dan martabat perempuan, yang berpoligami secara tidak sah, tanpa batas dan tidak bertanggungjawab terhadap wanita dan anak yang dilahirkannya atau konsep poligami yang terbatas, legal dan bertanggungjawab?

Di sisi lain tatkala jumlah populasi wanita lebih banyak dari laki-laki (demikianlah kecenderungan statistik kelahiran di berbagai negara). Sementara setiap laki-laki hanya dibolehkan menikah dengan satu orang perempuan, maka adil dan tegakah kita membiarkan wanitawanita menjadi barisan wanita-wanita janda dan perawan tua yang merana menunggu cinta tiba? Sementara itu pula terjadi di mana-mana peperangan, pembantaian, dan penjajahan yang menyebabkan terbunuhnya juataan kaum pria. Maka logiskah kalau kita mengatakan poligami itu adalah kekerasan terhadap harkat dan martabat perempuan? Yang logis adalah orang-orang yang menentang poligami itulah pelaku kekerasan yang bakiki.

Shener, seorang cendekiawan dan anggota parlemen perancis mengatakan:

\footnotetext{
${ }^{27}$ Mustafa Al-Siba'i, Al-Mar'ah bain alFiqh wa Al-Qanun diterjemahkan oleh Muhammad Muchson Anasy, Mengapa Poligam, h.51-53.
}

\begin{abstract}
"Dewasa ini di Perancis 1.500 .000 gadis yang belum mempunyai suami, sementara setiap penduduk Perancis hanya menikah dengan seorang wanita saja (monogami) dengan tegas saya katakan, bahwa seorang wanita tidak menikmati kesehatan prima dan ideal jika ia belum menjadi seorang ibu. Menurut keyakinan saya undang-undang yang mengatur mayoritas penduduk supaya mereka hidup bertentangan dengan hukum alam tersebut adalah undang-undang yang kejambahkan sangat tidak adil." $^{28}$
\end{abstract}

\section{Beberapa Hikmah Poligami}

Allah SW'T tidak menetapkan suatu syari'at melainkan ada hikmah di dalamnya, demikian halnya dengan syari'at kebolehan laki-laki untuk berpoligami dan pengharaman wanita untuk berpoliandri. Diantara hikmah itu, adalah sebagai berikut:

1. Kesesuaian antara ketetapan Allah menciptakan jumlah populasi wanita lebih banyak daripada kaum lelaki. Demikian pula kaum lelaki memiliki peluang yang lebih besar untuk tertimpa kematian dalam berbagai musibah. Jika lelaki dibatasi menikah hanya satu orang saja, maka akan terjadilah penumpukan wanita yang tidak menikah sehingga kondisi jika tidak dibarengi dengan penanaman keimanan yang kuat, akan tergiringlah mereka untuk melakukan perbuatan-perbuatan terhina seperti zina.

${ }^{28}$ Sufyan Raji Abdullah, Poligami dan Eksistensinya, h.88-89. 
2. Sesungguhnya wanita (jika menikah hanya dengan satu suami), ia itu haidh, sakit, nifas dan beberapa hambatan lain sehingga ia tidak bisa menunaikan tugastugas perkawinannya. Sedangkan kaum lelaki adalah sosok yang selalu siap untuk menambah jumlah ummat. Maka jika dirinya dikekang karena adanya udzurudzur yang dialami oleh wanita, maka tidak mustahil dengan keimanan yang lemah akan mencari penyaluran-penyaluran yang haram.

Sesungguhnya semua wanita secara prinsip siap untuk menikah. Namun banyak dari kalangan laki-laki yang tidak memiliki kemampuan untuk memenuhi tuntutan-tuntutan pernikahan karena kefakirannya. Dengan demikian, lelaki yang siap menikah jumlahnya jauh lebih sedikit dari pada kaum wanita. Maka jika kaum lelaki hanya dibatasi menikah dengan satu orang saja, kembali akan terjadi penumpukan wanita tanpa suami. ${ }^{29}$

\section{PENUTUP}

Dari uraian di atas, dapat ditarik beberapa kesimpulan, yaitu:

1. Poligami adalah perkawinan seorang lelaki dengan lebih dari satu orang wanita, yang sudah dikenal luas dan dipraktekkan oleh ummat terdahulu di berbagai belahan dunia. Sesudah diutusnya Nabi Muhammad saw, praktek poligami hanya dibolehkan sampai empat orang istri dengan syarat sang suami dapat berlaku adil (adil

${ }^{29}$ Syaikh Imād Zaki Al-Barudi,, Tafsir AlQur'an Al-Adzhim li An-Nisa' diterjemahkan oleh Samson Rahman, Tafsir Wanita, h.312-313. labiriyah) kepada seluruh istriistrinya.

2. Adanya berbagai persepsi yang keliru di kalangan ummat tentang poligami diakibatkan karena jauhnya mereka dari ajaran Islam yang murni dari Al Qur'an dan Sunnah Rasulullah saw seperti yang dipahama oleh para Ulama kita yang sholih dan istiqamah. Penyebab yang lainnya adalah hawa nafsu dan sifat apriori dengan poligami. Terlebih lagi Musuh-musuh Islam memanfaatkan isu poligami untuk menyerang Islam dengan berbagai tuduhan-tuduhan keji. Dimana tuduhan-tuduhan tersebut bersumber dari kebencian dan ada indikasi ketidak jujuran dalam memandang isu ini.

\section{DAFTAR PUSTAKA}

Kementrian Agama, Al-Qur'an dan Terjemahannya. Depok, Sabiq, 2012.

Abdullah, Sufyan Raji. Poligami dan Eksistensinya. Cet.I; Pustaka AlRiyadl, 2004.

Al-Barudi, Syaikh Imād Zaki. Tafsir Al-Qur'an Al-Adzbim li AnNisa' diterjemahkan oleh Samson Rahman Tafsir Wanita. Cet.I; Jakarta Timur: Pustaka Al-Kautsar, 2004.

Al-Qurțubī, Muḥammad bin Aḥmad. Al-Jāmi' Li Abkām Al-Qur'an, Jilid III. t.c. Dammām, Dār AlHadīis, 1423H/2002M.

Al-Sa'dī, Abdurrahmān Ibn Nāṣir. Taisì al-Karim al-Rabmān Fi Tafsì Kaläm al-Mannān, Jilid I. t.c., Dammām: Dār al-Dakhair, 1414H-1994M.

Al-Siba'i, Mustafa. Al-Mar'ab bain alFiqh wa Al-Qanun 
Website: https://journal.stiba.ac.id

ISSN : 2685-7537 (online) 2338-5251 (Printed)

diterjemahkan oleh

Muhammad Muchson Anasy dengan judul "Mengapa Poligami". Cet.I; Azan-Yayasan Adjeng Suharno, $1423 \mathrm{H} /$ Oktober 2002M.

Al-Sijistanī, Abū Dāud Sulaimān Ibn Al-Asy'as. Sunan Abì Dāud, Jilid II. Bairūt, Dār al-Kitāb alArabī, $1346 \mathrm{H}$.

Al-Ṭabarī, Abī Ja'far bin Jarīr. Jämi' AlBayān Fi Ta'wäl Al-Qur'an, Jilid IV. Cet.III, Dammām, Dār alKutub, 1420H-1994M.

Ghazalba, Sidi. Menghadapi Soal-soal Perkawinan. Cet.I; Pustaka Antara, Jakarta ,1975.

Ibn KaS̀īr, Imāduddīn Abul Fidā' Ismāīl.Tafsìr Al-Qur'ān Al'Ażim, Jilid I. t.c., Al Madīnah Al-Munawwarah: Maktabah Al-'Ulūm wa Al-Hikam, 1413H-1993M.

Ibnul Arabī, Abū Bakr Muḥammad Ibn Abdillāh. Abkèm AlQur'ān, Jilid I. t.c.Beirut, Dār Al-'Ilmiyah, 1417H/1996 M.

www.lbh-apik.or.id/sm-pers-

poligami.htm. 